\title{
Preparation of the spherical clay and its application to the functional powder
}

\author{
Kazuo Tokubo and Michihiro Yamaguchi
}

The swelling clay is mainly used as the gel agent in cosmetics. In this study, the swelling clay has been applied to the body of the functional powder in cosmetics, taking advantage of its gelation ability and property of intercalation.

The nobel spherical clay was obtained by spray drying the hydro gel of a synthetic hectorite. No swelling clay other than the synthetic hectorite was formed sphericaly in shape by the spray drying process. This is the reason the particle size of this synthetic hectorite is very small, c. a. $100 \AA$, compared with that of the other swelling clay.

Making use of this preparation of the spherical clay, two types of the spherical functional powder have been developed by the way of spray drying the gel of the synthetic hectorite including the various functional material. The first type is the spherical powder containing the functional molecules intecalated in the interlayer of the clay particle. The functional molecules are, for example, moisturizer, perfume, antimicrobial agent, UV absober, dye and so on. The spherical clay intercalating glycerin as the functional molecule has been prepared as the moisutre powder. This powder has a high fluidity even though the amount of glycerin in this powder is $40 \%$ by weight.

On the second type of the spherical powder, the fine particle is selected as the functional material. This spherical functional powder contains uniformly fine particles both to the surface and inside of the powder. The fine particles such as titanium dioxide, zinc oxide and ferric oxide, or these colloidal particles can be embeded in the powder as the functional particles. In the case of the titanium dioxide, the surface activity of titanium dioxide has been suppressed because most titanium dioxide particles are embeded in the powder. This spherical powder showed excellent slippage and useability, exhibiting UV protect effect.

These powder will be used conveniently in many cosmetics, exhibiting each function according to the functional material contained.

\section{1. 緒 言}

\section{膨潤性粘土鉱物は化粧品に括いてそのゲル化能を利用} し，主にゲル化剤として用いられてきた。水系のゲルと して, 乳液, 水系アイライナーや洗浄剤などに, また溶 郕・油系のゲルとしては有機变性された粘土鉱物が，工 ナメル，油性アイライナーなどに利用されている。

一方, 膨潤性粘土鉱物の特性としてゲル化能の他に,

(株)資生堂基礎科学研究所： $\mathbf{T} 223$ 横浜市港北区新羽町 1050

Shiseido Basic Research Laboratories.: $1050 \mathrm{Ni}-$ ppa-cho, Kohoku-ku, Yokohama, Japan
その層間にカチオン性分子や極性分子を包接する性質が ある11。このような包接現象はインーカレーション (Intercalation) 之呼ばれ古くから研究されている。本研究 では，これらのゲル化和よび包接作用を利用して，各種 機能性物質と粘土鉱物を複合化させた新しい機能性粉体 の開発を目的とした。

ここで開発した粉体は，担体が熱的にも機械的にも安 定な粘土鉱物であり，機能性物質が表面だけでなく内部 にも存在すること，㧊よび機能性物質として無機粉体の みならず液体状分子も複合化が可能であることが大きな 特徴となっている。本報文ではこの新しい機能性粉体の 調製法といくつかの応用例について述べる。 


\section{2. 実 験}

\section{1 試 料}

本研究で用いた膨潤性粘土鉱物は鉱物学的にはSmectite 族に属し，Fig.-1 に示すように 2: 1 型の層状ヶイ 酸塩鉱物であり，一層の厚さは $9.8 \AA ，$ 層と層の間は約 $5 \AA$ ある。そして四面体シート中のケイ素のアルミニウ ムによる置換, あるいは八面体シート中の三価陽イオン の二価陽イオン，または二価陽イオンの一価陽イオンに よる置換によって負電荷を生じているが，この負電荷は 層間の陽イオンにより相殺されている。

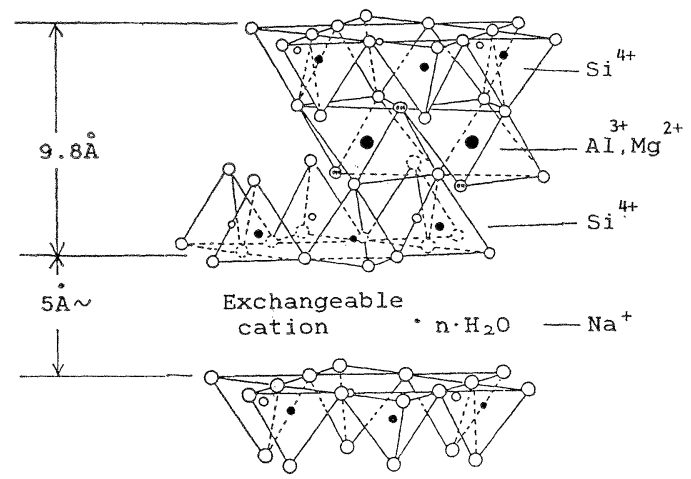

Fig.-1 The structure of the swelling clay.

膨潤性粘土鉱物の特徴は，アルコール類，アミン類， エステル類などの各種極性分子を層間に取り込むこと特 よび層間のナトリウムイオンが各種のカチオンと容易に 交換可能なことである。層間距離は通常では $15 \AA$ 程度で あるが，ナトリウムイオンに比べ分子の大きなカチオン や極性分子が層間に入った場合には，分子の大きさに伴 い層間距離は抎がってくる。

膨潤性粘土鉱物としては，天然品のモンモリロナイ ト，合成サポナイト跨よび合成へクトライトを用いた。 粘土鉱物に複合化させるグリセリンは試薬特級を，微粒 子二酸化チタンは P-25（デグサ社）を用いた。

\section{2 調製法}

機能性物質と膨潤性粘土鉱物の複合粉末は，機能性物 質を水に溶解または分散し，そこに膨潤性粘土鉱物を分 散して機能性物質を含んだゲルを作り，このダルをスプ レー・ドライして調製した。

スプレー・ドライヤーは卓上型スプレー・ドライヤー SD-1 型（二流体ノズル式，東京理化）执よびモービル マイナー型スプレー・ドライヤー（回転円盤式，アシザ
ワ・ニロアトマイザー)を用いた。

\section{3 測定法}

\subsection{1 球状粘土鉣物の観察}

得られた粉体の観察には光学顕微鏡, 走査型電子顕微 鏡（S-450 型，日立製作所）扣よび面分析をするために 走查透過型電子顕鏡（H-800 型，日立製作所）とX線分 析装置（EDX-7500 型，kevex 社）を用いた。

\subsection{2 比表面積測定}

粘土鉱物の比表面積は比表面積自動測定装置 2200 型 （島津製作所）を用小，窒素吸着法により求めた。

2.3.3 粒度分布測定

膨潤性粘土鉱物の粒度分布は, サブミクロン粒度分 布測定装置 NICOMP-270 (HIAC/ROYCO 社) を用い た。

\subsection{4 安息角の測定}

粉体の流動性を評価するため，パウダーテスターRT一 $\mathrm{D}$ 型（細川粉体工学研究所）を用いて安息角の測定を行 つた。

\subsubsection{X線回折測定}

粘土鉱物の層間距離は粉末 $\mathrm{X}$ 線回折測定により求め た。日本電子 JRX-12VAを用いて, $\mathrm{Cu}-\mathrm{K} \alpha$ 線により， 40KV-150mA で Scanning Speed $1 / 4^{\circ} / \min$ にて 測定した。

層間距離は層間に存在する水分子の量によって影響を 受けるので，粉体を $150^{\circ} \mathrm{C} て ゙$ 㲦燥して水分子を層間から 除去して測定した。

\subsubsection{TG-DTA 測定}

TG-DTA 測定には示差熱-重量同時測定装置 SSC／ $560 \mathrm{GH}$ (セイコ一電子工業) で昇温スピード $10^{\circ} \mathrm{C} / \mathrm{min}$ にて測定した。

\subsubsection{IR 測定}

IR 測定は FTS15C (Digilab 社) を用い, KBr を希 釈剤とした拡散反射法で測定した。

\section{3 .8 粉体の吸湿性}

それぞれの粉体の吸湿性は，イオン交換水を大れたデ シケーター中に粉末を置き，それを $37^{\circ} \mathrm{C}$ に保った時の 粉末の吸湿による重量增加から評価した。

\subsection{9 グリセリンの溶出}

グリセリン包接球状粘土鉱物からのグリセりンの水へ の溶出速度は，グリセリンを $25 \%$ 包接した球状粘土鉱物 を $1.0 \mathrm{~g}$ 科りとり，それを孔径 $0.1 \mu \mathrm{m}$ のミリポアフィル タ一の袋に入れその袋を $70 \mathrm{ml}$ のイオン交換水に浸し， 球状粘土鉱物からイオン交換水に溶出したグリセりン量 るガスクロマトグラフで定量することによって求めた。 


\section{3. 結果と考察}

\section{1 ゲルの乾燥上球状粉体の生成}

各膨閵性粘士鉱物のゲルを乾燥して粉末を得る場合， 监なる加熱により乾燥すると堅い凝集体となり粉碎して 微䊀子化することは困難ですった。凍結乾燥では，和牱 きな柔らかい薄片状となり微粒子化ができなかった。一

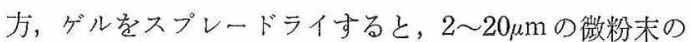
料土鉱物が得られた。これらの粉末の走查型電子顕微鏡

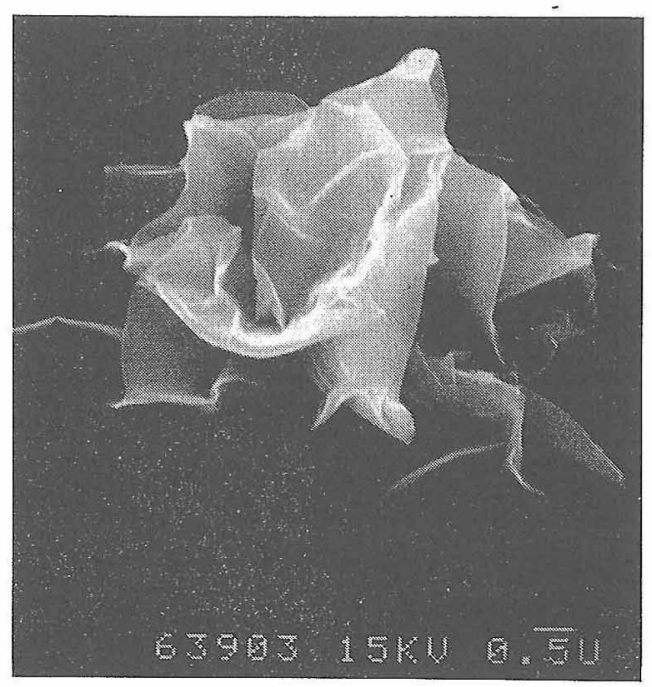

Montmorillonite

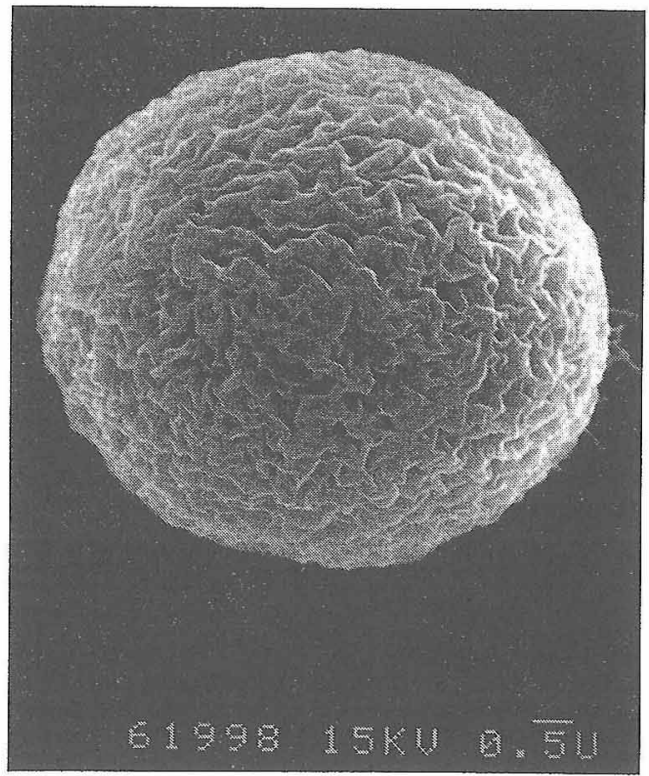

Saponite
写真 (SEM 写真) を Fig.-2 炕示す。モンモリロナイ トではひだ状の薄片状粉末であり, サポナイトでは表面 がひだ模様の球状粉末, へクトライトでは表面がなめら かな真球状粉末となった。へクトライトから生成した粉 末は球状であるため，すべりの良い使用性の優れたる のであった。表面を拡大した SEM 写真をFig.-3 K示 す。なめらか㹸党た表面も桩大して見れば微細なひだ 模様が形成されて拉り，この粉末は極めて細か、微粒子 の凝集体で西ることがうかが党る。

\section{2 球状粉体の生成機構}

検討した粘土釷物のららスプレー・ドライ調製法によ ク、ヘクトライトだけが表面のなめらかな球状粉体とな った理由について考察した2)。

回転円盤式のスプレー・ドライヤーの概略図を Fig.-4 に示す。この装置では加熱された空気がアトマイザー部 に送られ，サイクロン部で吸引されている。一方ポンプ よりダルがスプレー・ドライヤーのアトマイザー部分に 一定流量で尊入されるが，この㭙アトマイザーは高速で 回転して拈りダルの水滴は加熱空気の流れに乗ってサイ クロン部に行く途中で徐々に針燥され, 最終的に乾燥粉 末となりサイクロン部に捕集される。

それぞれの膨潤性粘土鉣物の比表面積と水中での粒度 分布を Table-1 亿示寸。䇪素吸着法より求めた比表面 積は，モンモりロイトで $12.4 \mathrm{~m}^{2} / \mathrm{g}$ であるのに比烄して

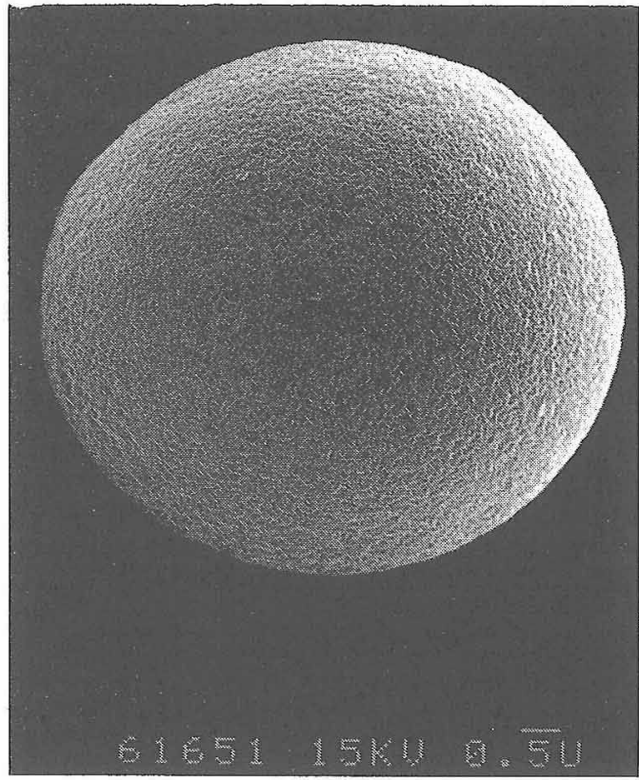

Hectorite

Fig.-2 Powders prepared from swelling clay dispersions by spray drying. 


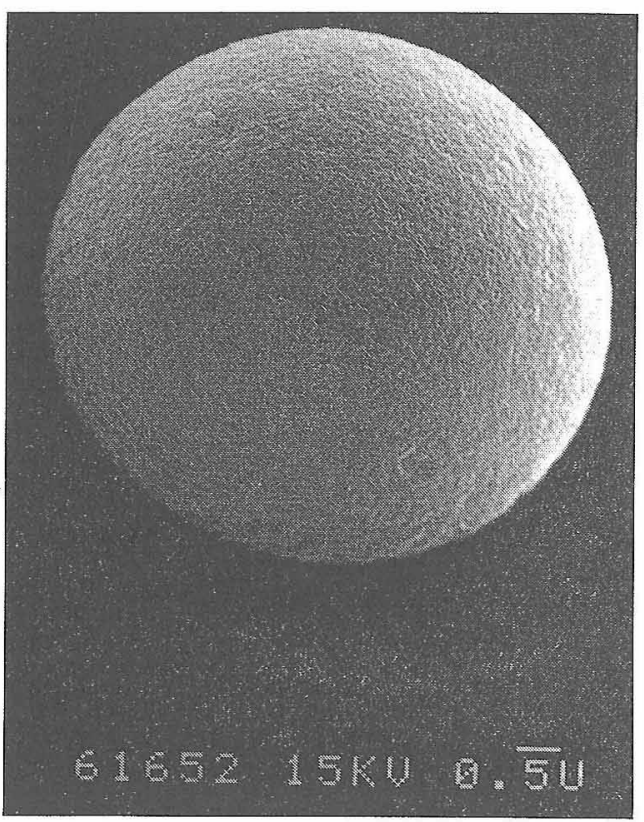

$(\times 10,000)$

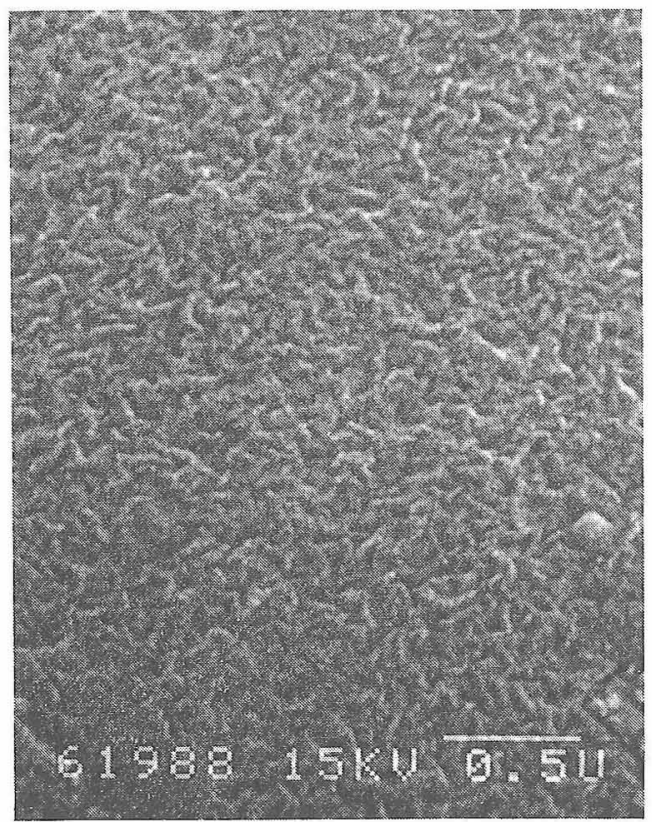

$(\times 30,000)$

Fig.-3 Spherical clay prepared from hectorite by spray drying.

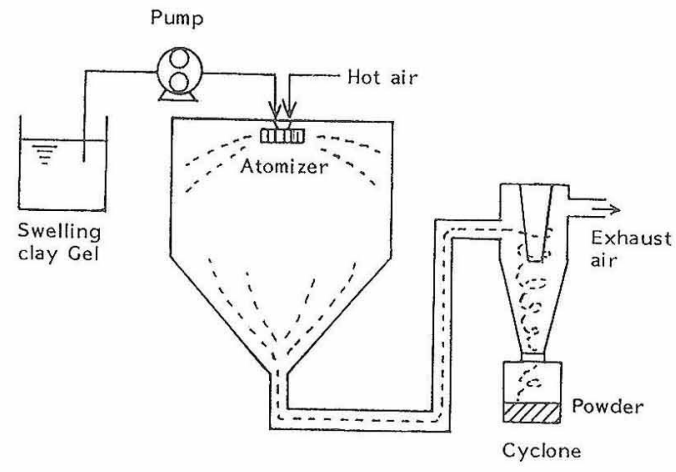

Fig.-4 Schematic diagram of the spray dryer.

Table-1 Surface area and diameter of swelling clay.

Montmorillonite Saponite Hectorite

\begin{tabular}{lccc}
\hline Surface area, $\mathrm{m}^{2} / \mathrm{g}$ & 12.4 & 129 & 350 \\
(Diameter, $\mu \mathrm{m}) *$ & $(0.18)$ & $(0.02)$ & $(0.007)$ \\
Ave. Diameter, $\mu \mathrm{m} * *$ & 0.53 & 0.092 & 0.034
\end{tabular}

* values calculated from surface area.

** values measured with dynamic light scattering.

ヘクトライトでは $350 \mathrm{~m}^{2} / \mathrm{g}$ 極めて大きかった。このへ クトライトの值を球径換算して，その平均粒子径を求め
ると $0.01 \mu \mathrm{m}$ 以下の微粒子であり, NICOMP より求め た平均粒子径でもへクトライトが $0.034 \mu \mathrm{m}$ と一番小さ い值を示した。サブミクロン粒度分布測定装置での平均 粒子径が比表面積から計算した值より大きくなったの は，水中でへクトライトがある程度凝集しているためと 考えられる。このように, へクトライトは他の膨潤性粘 土鉣物に比べて粘土鉱物を構成する一次粒子が極めて小 さいことが分った。

ゲルのスプレー・ドライによって得られる粉末の大き さは，アトマイザーの回転速度やノズル径にも関係する

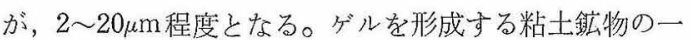
次粒子が平板状であり，艺の大きさがモンモリロナイト のように数 $\mu \mathrm{m}$ にるなる，乾燥されて生成した一次粒 子の凝集体である粉末は球状とはなり得ない。一次粒子 が十分に小さければ，水榈は表面張力により球状である ことから，乾燥粉末球として得られるものと思われ る。したがって，モンモリロナイトはその一次粒子が大 さいため球状とはなり得ず，一次粒子の小さいいクトラ イトほぞ球状になり易い。サポナイトでは一次粒子の大 さが，モンモリロナイトとへクトライトの中間にあるた め, 球状に近い形にはなるがその表面はFig.-5のSEM 写真が示すように，一次粒子の凝集体を示す大きなひだ 模様が形成されてしまら。へクトライトの場合は，气の 


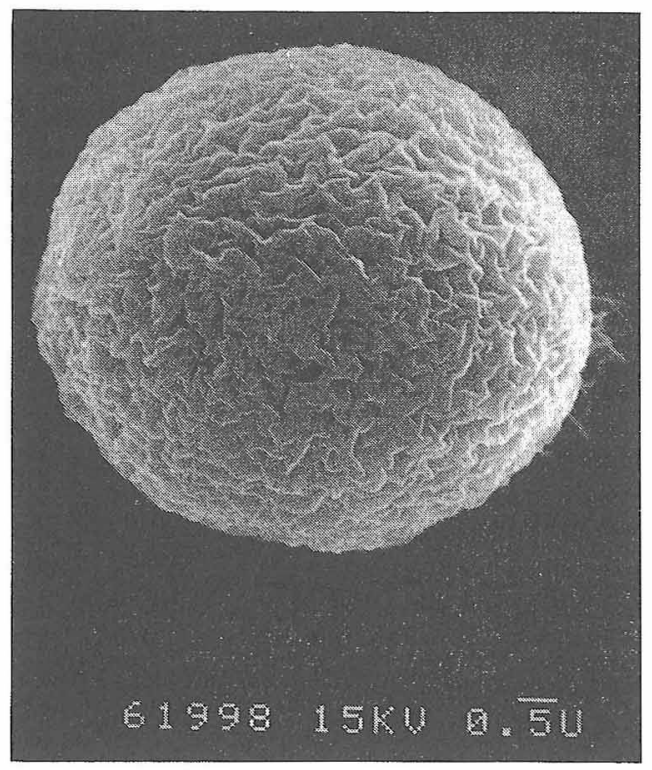

$(\times 10,000)$

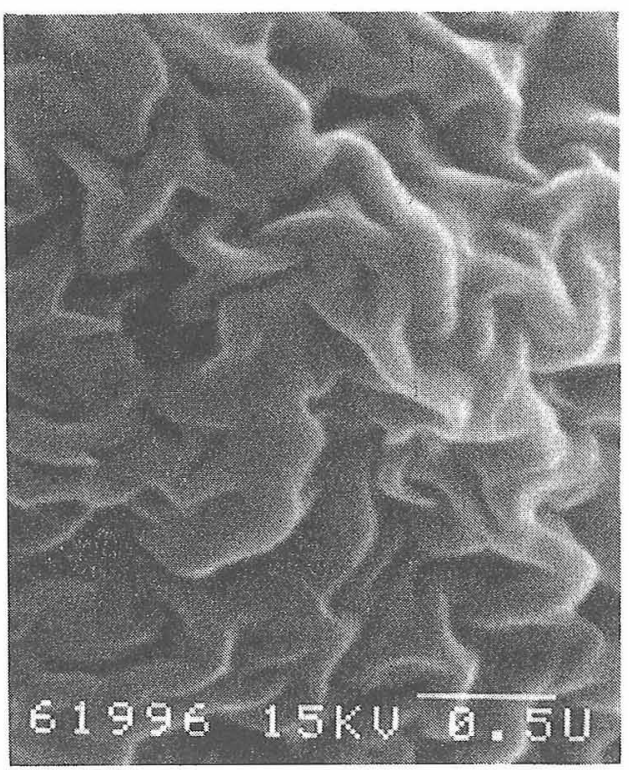

$(\times 30,000)$

Fig.-5 Quasi-spherical clay prepared from saponite by spray drying.

一次粒子が極めて小さいために，表面がよりなめらかに 見党ると考党られた。

\section{3 球状粘土鉱物を利用した機能性粉体の開発}

球状粘土鉣物を担体とした機能性粉体には，機能性物 質によって大きく二つに分けられる。その一つは機能性 物質が分子であり，もら一つは微粒子の場合である。機 能性分子の場合はそれをへクトライトの層間に包接した 球状粘土鉱物であり，機能性微精子の場合はそれを内部 に均一に点在させ包埋した球状粘土釷物である。Fig.-6 にそれら機能性物質の存在場所の模式図を示す。

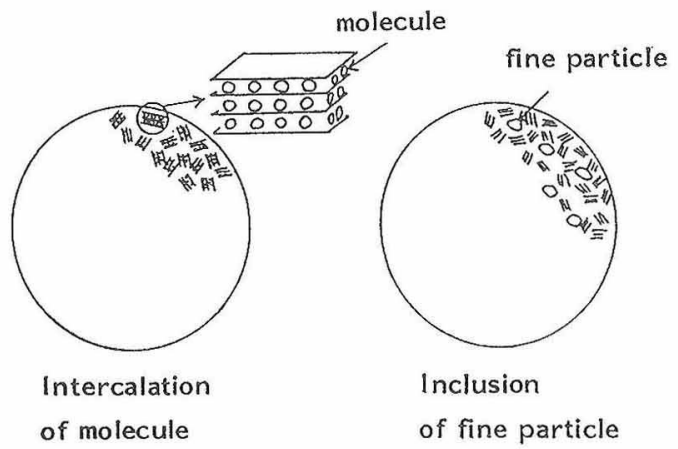

Fig.-6 Two types of the spherical functional clay.

機能性分子包接の応用例として保湿作用の優れたグリ セリンを, 機能性微粒子包埋の応用例として紫外線防御
能に優れている微粒子二酸化チタンを複合化させた機能 性粉体について述べる。

\subsection{1 グリセリン包接球状粘土鉱物}

この方法により液体状の物質との複合化ができ, 液体 分子の粉末化が可能となった。グリセリンは極性の高い 液状物質であり，锠来は粉末製品や口紅に配合すること は困難であったが，グリセリンを複合化した球状粘土鉱 物を用いると，これらの製品にグリセリンが配合可能と なった。

(1) 調製

グリセリンをイオン交換水に溶解し，そこにへクトラ イトを $3 \%$ 分散させ調製したゲルをスプレー・ドライし た。

このようにして調製した，グリセリンを $25 \%$ 包接し た球状粘土鉱物の光学 括よび 走查型電子顕微鏡写真を Fig. -7 に示寸。写真の上らに球状粘土鈗物は表面のな めらかな真球状粉体であった。

(2) グリセリンの包接現象

a) X線回折測定

グリセリンが，0，10，40\%存在している球状粘土釷物 の低角側のX線回折パターンをFig.-8 に示す。(001) 面の回折ピークはグリセリンが存在するとンャープとな りグリセリンが層間に刨接されることによって層の規 則性が高まることが予想された。さらに回折ピークは低 

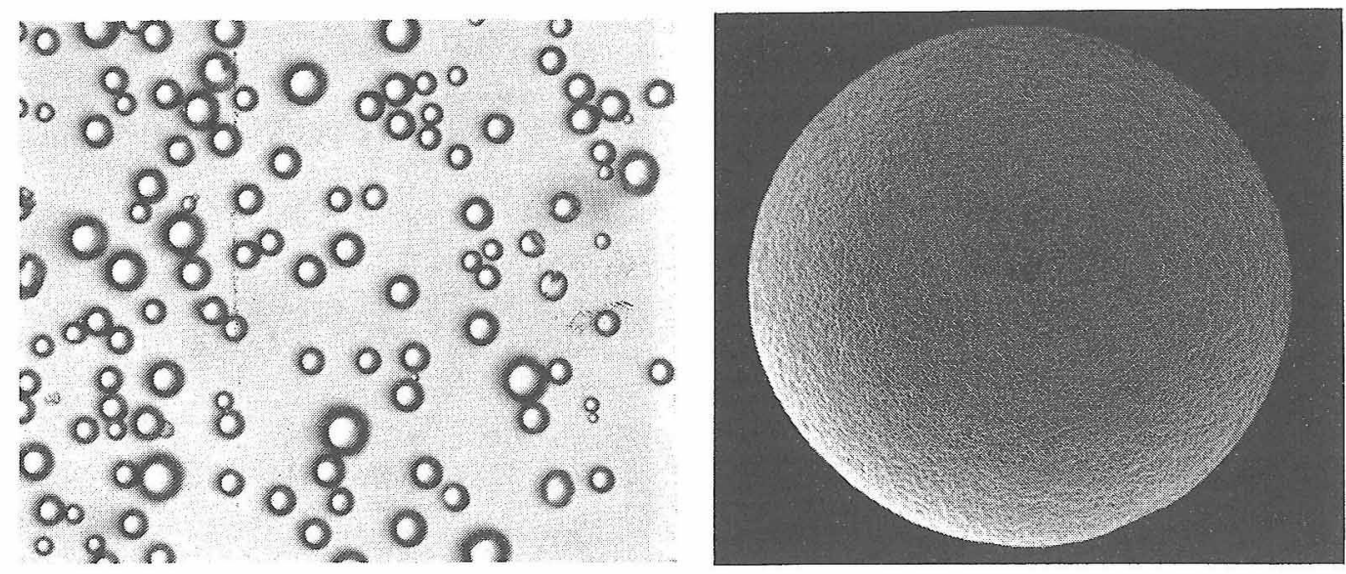

$(\times 10,000)$

Fig. -7 Spherical clay intercalating $25 \mathrm{wt} \%$ glycerin.

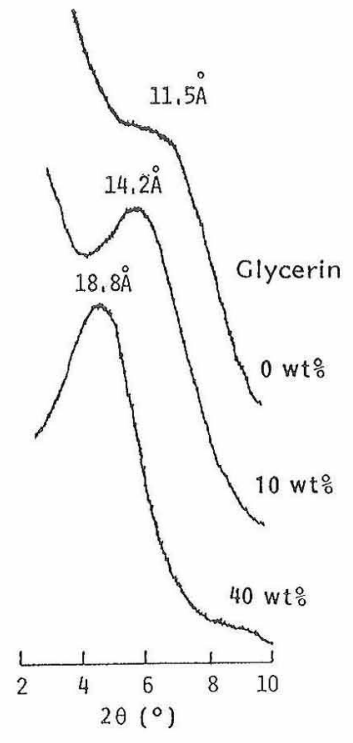

Fig.-8 XRD of spherical clay intercalating glycerin.

角度にシフトすることから層間が拡がっていることが分 かる。グリセリン量と層間距離の関係を Fig. -9 飞示 す。グリセリン量が增すとついて層間距離は桩がって拉 りグリセリンが層間に包接されていることが確認でき た。またグリセリンが20～30\%のところでプラトーが認 められ，層間距離の拡がりとグリセリンの分子の大きさ から，ここまではグリセリンが層間に一分子包接され， それ以降は二分子包接されたものと思われる。

b) TG-DTA 测定

ヘクトライトとグリセリンを $25 \%$ 创接した球状粘土鉱

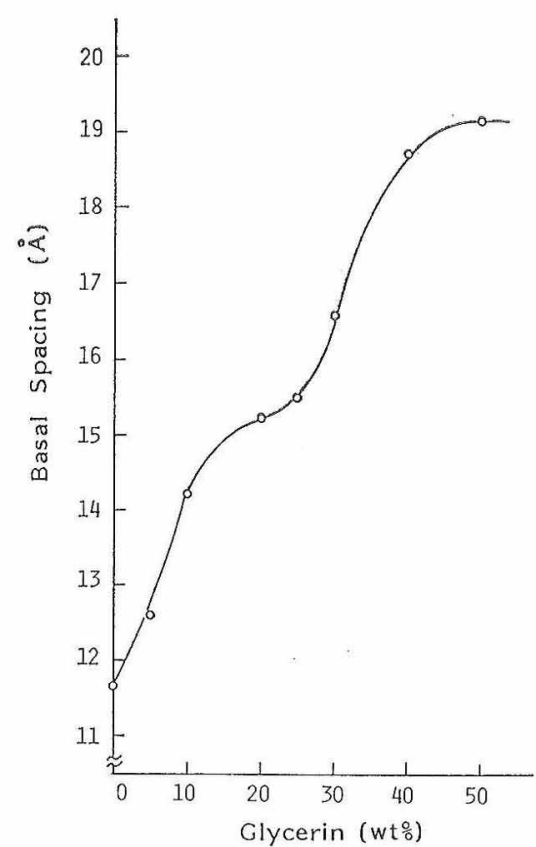

Fig.-9 Basal spacing of spherical clay intercalating glycerin.

物の TG-DTA 測定結果を Fig.-10 K示す。いずれる $150^{\circ} \mathrm{C}$ 位までに, 粉体表面の付着水および層間水の離脱 による吸熱ピークとそれに伴ら重量減少が認められた。 さらにグリセりン包接の球状粘上鉱物では $280^{\circ} \mathrm{C}$ 付近か ら大きな発熱ピークとそれに伴う重量減少が現れた。重 量減少量は約 $25 \%$ であり, これは存在するグリセリン量 に対応している。このことから，このピークはグリセり ンの燃焼によるものであると思われる。Fig.-10 にはグ 


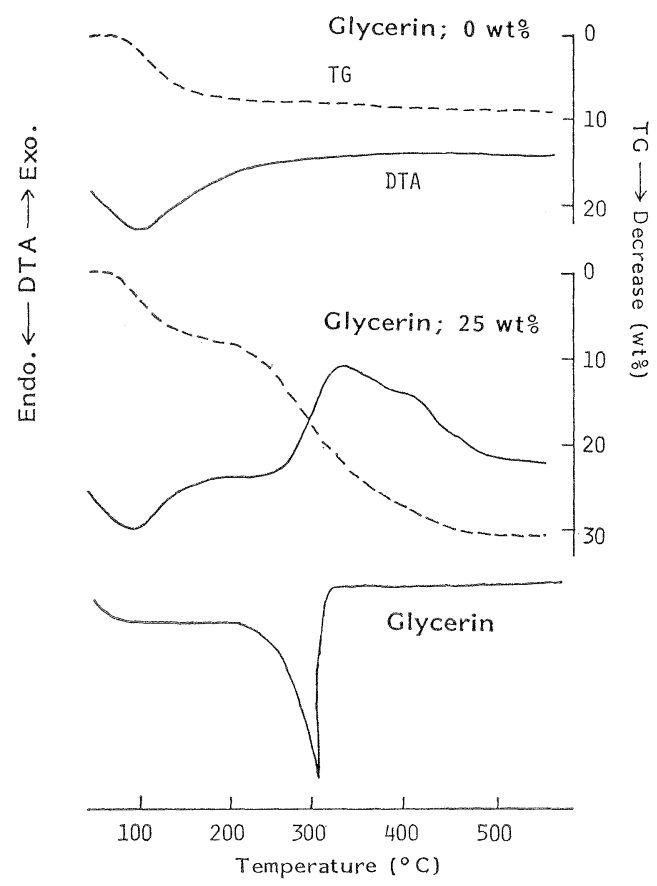

Fig.-10 TG-DTA curves of spherical clay intercalating glycerin.

セリンのみの TG-DTA 測定結果も示しているが，ここ では蒸発による吸熱ピークが $200^{\circ} \mathrm{C}$ 付近から現れた。球 状粘土銗物中のグリセりンは蒸発ではなく $280^{\circ} \mathrm{C}$ 以上で 燃焼していることから，グリセリンは分子としでへクト

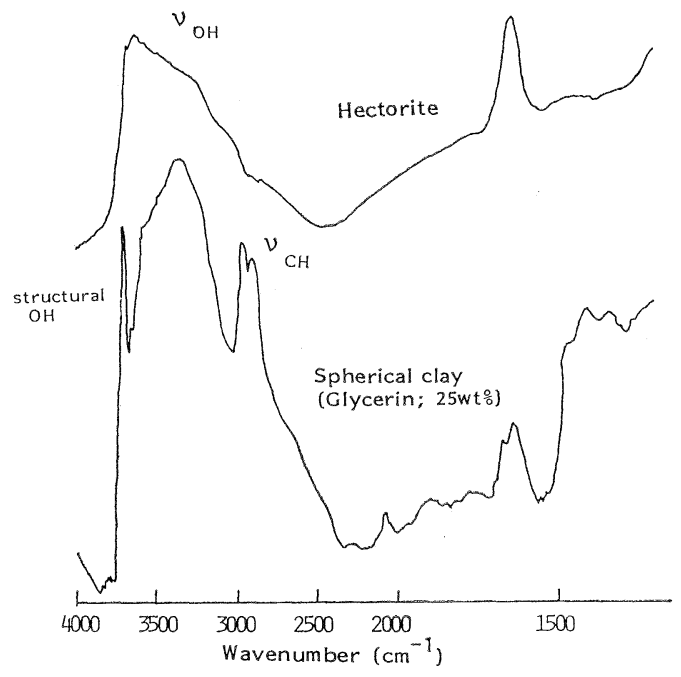

Fig.-11 FT-IR spectra of spherical clay intercalating $25 \mathrm{wt} \%$ glycerin.
ライト層間に強く吸着していることがうかがえる。

c) IR 測定

Fig.-11にへクトライトとグリセリンを $25 \%$ 包接した 球状粘土鉱物の FT-IR 測定結果を示す。へクトライト では $3000 \sim 3700 \mathrm{~cm}^{-1}$ に層間水の水酸基とへクトライト の構造自体に含まれる水酸基（構造 $\mathrm{OH}$ ）の伸縮振動が 重なって現机た。一力, 球状粘土鉱物ではこのへクトラ イトのピークに，グリセリンの $3000 \sim 3500 \mathrm{~cm}^{-1}$ の水酸 基伸縮振動と $2700 \sim 2800 \mathrm{~cm}^{-1}$ の $\mathrm{CH}$ の伸縮振動が重な って扣りグリセリンが存在することを示している。ここ で特徴的なことは $3700 \mathrm{~cm}^{-1}$ にピークが鋭く分離して出

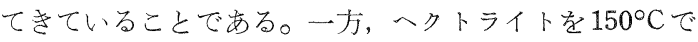
加熱すると同様に $3700 \mathrm{~cm}^{-1}$ のピークが出現する。この 場合は，加熱により層間水が離脱して水分子の水酸基が 少なくなり，へクトライト中の構造水酸基が分離された ものと考光られる。このことから, 球状粘土鉱物の 3700 $\mathrm{cm}^{-1}$ のピークの分離は，グリセリンが靨間に入ったた め廨間水がグリセリンと置換し層閒から離脱したことを 意味している。

以上のように，X線回折，TG-DTA 和よびIR 測定か ら, 球状粘土鉣物中のグリセリンはへクトライトの層間 に包接されていることが明らかとなった。

（3）グリセリン包接球状粘土鉣物の粉体特性

a）安息角の測定

Table-2 ヒグリセリンを包接した球状粘土鉱物和よび タルク，マイカと各種有機球状粉末の安息角の值を示 す。グリセリンを $40 \%$ まで包接しても安息角は他の粉末 より小さく，グリセリンが多量に存在しても凝集性の弱 いサラサラした粉体であることが分かる。これはグリセ リンがヘクトライト表面に付着しているのではなく，分

Table-2 Angles of repose of various powders.

\begin{tabular}{ccc}
\hline & \multicolumn{2}{c}{ Angle of Repose $\left(^{\circ}\right)$} \\
\hline Spherical clay & Glycerin (wt \%) & \\
& 0 & 40 \\
& 20 & 45 \\
& 30 & 48 \\
& 40 & 58 \\
\hline Talc & & 58 \\
Mica & & 60 \\
PE powder & 50 \\
PMMA powder & 62 \\
Nylon powder & 70 \\
Cellulose powder & 72 \\
\hline
\end{tabular}


子として層間に包接されているためである。

b) 吸湿性

$37^{\circ} \mathrm{C}$ ，相詨湿度 $100 \%$ で粉体の吸湿性を経時による 重量增加で調べた。 Fig.-12から分るようにグリセリン 存包接していない球状粘士㼡物でる，吸湿性のあるセル ロースパウダーより高い吸湿性を示した。グリセりンを 包接した球状粘土鈆物では，その包接量に応じてさらに 高い吸湿性を示し，グリリンの包接量が50\%になると 保湿拜として用いられているヒアルロン酸以上の吸湿性

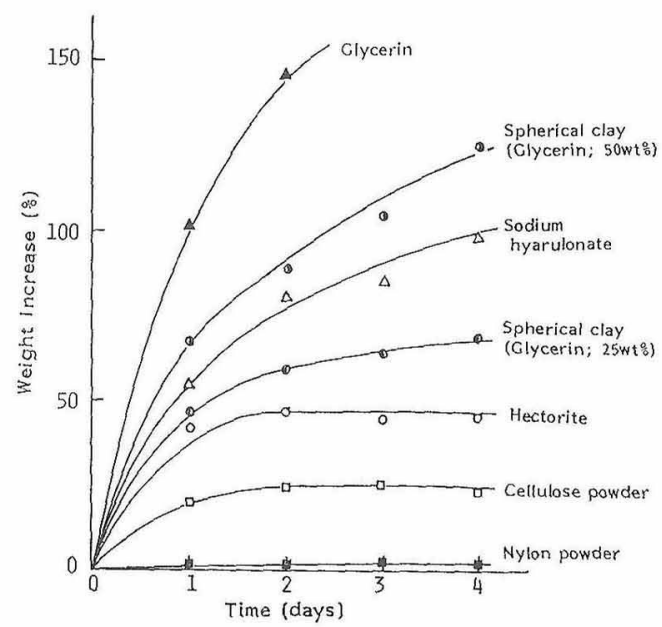

Fig.-12 Moisture absorption of spherical clay intercalating glycerin. ( $100 \%$ R.H., $\left.37^{\circ} \mathrm{C}\right)$

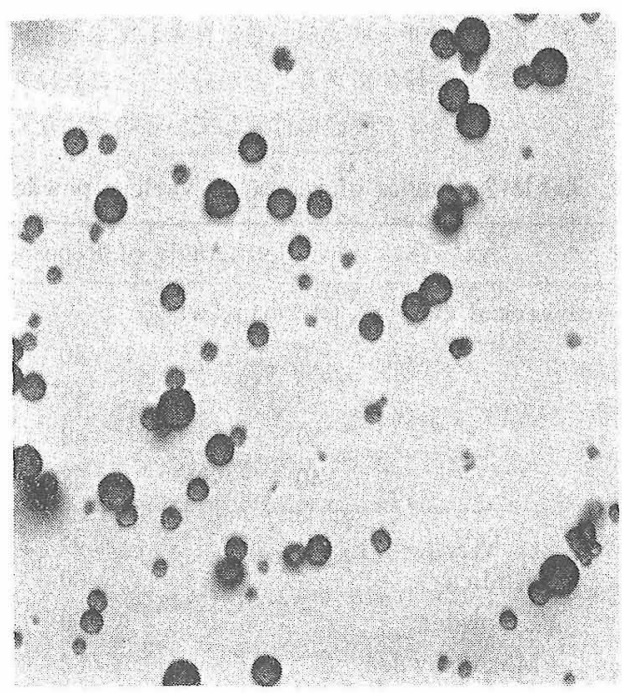

であった。このよらにグリセりン包接球粘土鉱物は高い 吸湿性があり，保湿作用が期待できると考兄られる。 たこのよらに吸混しても粒子の大きさにはほとんど变 化はない。

c）水へのグリ七リンの溶出

水之接した時の層間に包接されたダリセリンの溶出举 動を調ベた。グリセリンのみと $25 \%$ グリセリン包接球状 粘土鈗物の水への溶出の様子を Fig.-13に示す。図のよ らに球状粘土銗物に包接されたグリセリンは水と接する ことによって層間から溶出され，包接された状態でもグ リセリンの機能が発揮できると考学られた。さらにその 溶出はグリセリンと去ののと比べて, 徐々に溶出してき て捈放作用が認められた。

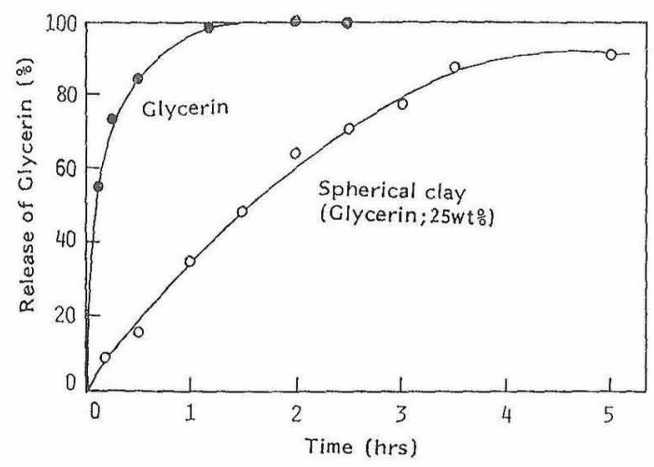

Fig.-13 Release of glycerin from spherical clay intercalating $25 \mathrm{wt} \%$ glycerin.

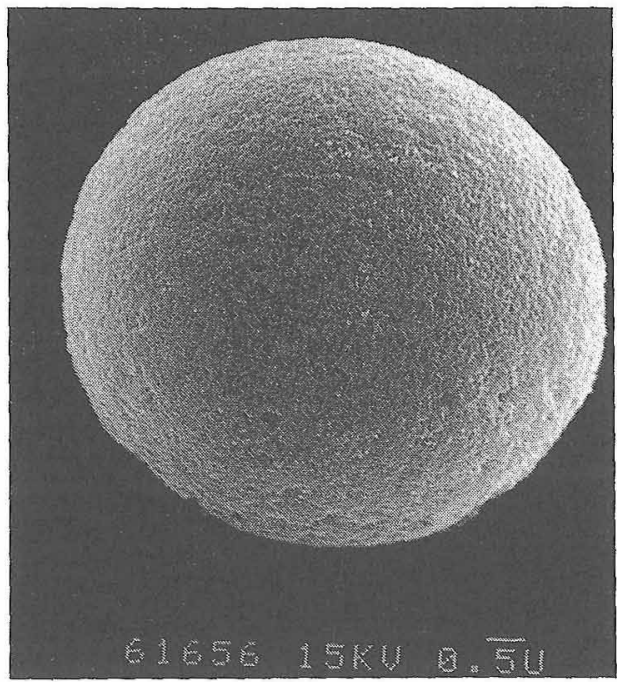

$(\times 10,000)$

Fig.-14 Spherical clay including $25 \mathrm{wt} \% \mathrm{TiO}_{2}$ 


\subsection{2 微粒子二酸化チタン包埋球状粘土鉱物}

機能性粉体のもら一つのタイプは機能性物質が $0.1 \mu \mathrm{m}$ 以下の徽粒子の場合であり，これを包埋した球状粘士鉱 物である。ここでは微粒子二酸陵化チタンを包埋させた 例を示す。

\section{(1) 調製}

微䊀子二酸化チタンをイオン交換水に分敞し，そこに ヘクトライトをさらに分散させ，二酸化ヂンがよく分 散したゲルを調佂する。二酸化チタンは水に分散しにく いが，ヘクトライトの痖在によりその分散性は良好之な る。このゲルをスプレー・ドライすることによって微粘 子二酸化子夕ン包埋球粘土鉱物学得た。

二酸化チタンを $25 \%$ 包埋するよう淍製した粉体の光学 顕微鏡および SEM 写真を Fig.-14 K示す。このように 表面のなめらかな球状粉体がでさていることが分かる。

(2) 粉体中の二酸化チタンの存在状態

二酸化チタンの存在状態を調ベるため，この粉体を走 查透過型電顕とX線分析を用いてチタンの線分析と面分 析を行った。Fig.-15K示すようにチタンの存在学示す スポットが粉体全体に均一に認められ, 二酸化テタンが 粉体内部に均一に包埋されていることが碓かるられた。

微粒子二酸化チタンには紫外線汸御効果があるが，こ

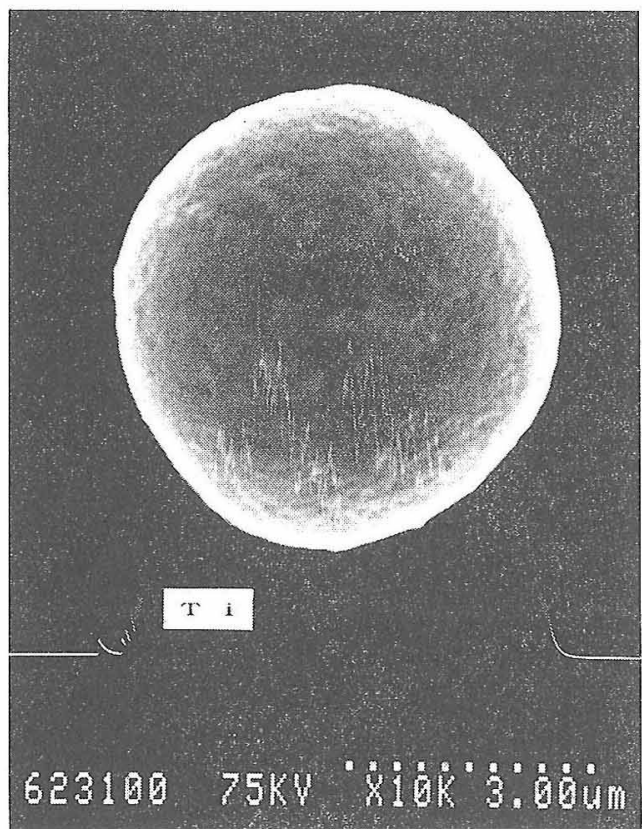

Ti line profile
のよらにして調製した球状粘土鉱物にむ微粒子二酸化于 タンが均一に创埋されていることから，同様な紫外線防 御効果が認められた。

この粉体では二酸化チタンの多くが粉体内部に存在す るため，二酸化チタンの表䣫活性によるオイルなどの劣 化の抑制が期待でさる。

\section{4. 総 括}

ゲル化肪である膨潤性粘土鉱物をそのゲル化能と刨接 能学利用し，機能性粉体の担体として用いることを検剧 した。その結果，次のよらな機能性粉体が開発できた。

(1) 膨潤性粘士鉱物としてへクトライトを用いて，そ のゲルをスプレードライすることによって球状の粉 体を得ることができた。この球状の粉体は粘土鉱物 の一次粒子が球状に凝集したものである。検討した 粘土钩物のなかでへクトライトのみが球状になった のは，この粘土铈物が他のものに比べ一次粒子が $100 \AA$ 程度と非㦂に小さいためであった。このこと を利用して㙨能性物筫を含んだへクトライトのゲル をスプレー。ドラてイし，二つのタイプの機能性粉 体表開発した。

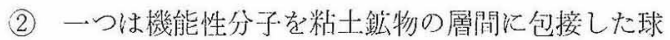

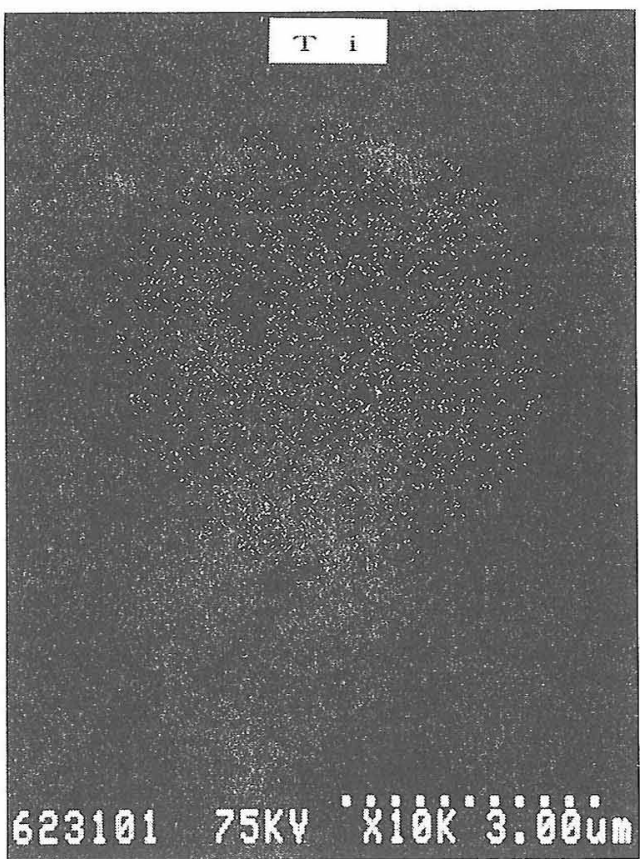

Ti x-ray map

Fig.-15 Analysis of $\mathrm{TiO}_{2}$ included in spherical clay.

J. Soc. Cosmet. Chem. Japan. Vol.24, No.2 1990 
状の機能性粉体であり，ここで化粧品に利用できる 機能性分子として保湿剂, 香料, 染料, 防腐剂, 紫 外線吸収剤などがあげられる。この方法により，液 状物質の粉末化が可能となる。

グリセリンを包接させた球状粉体では，40\%がグ リセリンであってもべタつかない流動性のすぐれた 粉末となった。これはグリセりンが単に粘土鉱物表 面に吸着しているのではなく，分子として粘土鉱 物の一次粒子の層間に包接されているためである。 このことは, X線回折からの層間距離の拡がり, TG-DTA測定からの高温でのグリセリンの燃焼, IR 測定に持けるグリセリンのピークの確認により明ら かとなった。さらにこの粉体は複合化されているグ リセリン量に応じて吸湿性を示し，また水分と接す ると包接されていたグリセリンが溶出することか ら，肌上で保湿作用が発揮でさると考学られる。

グリセリンのように機能性分子が水溶性の場合 は, これが溶解したへクトライトの水性ゲルをスプ レー・ドライすればよい。水に溶解しない場合に
は，最初に何尼包接していない球状粘土鉱物をスプ レー・ドライにより調製する。次に機能性分子を有 機溶媒に溶解し，そこに球状粘土鉣物を分散させた 後, 有期溶媒を留去すればよい。有機溶媒が除去さ れるにしたがい機能性分子は強制的に粘土釷物の層 間に包接されていく。この方法により香料を包接さ せると，この粉体は水に接すると香料を放出すると いった性質を示す。

（3）機能性物質が微粒子の場合には，これを粉体内部 に均一に包埋した機能性粉体となる。微粒子として 二酸化チタンを用いれば,なめらかな使用性を有 し, 二酸化チタンの表面活性のない紫外線防御性粉 体が調製でさる。

\section{文 献}

1) K.G. Theng, "The Chemistry of Clay-Organic Reactions” (1974) Adam Hilger, London

2) “最新造粒技術の実際”（1984）神奈川経営開発七 ンター

(平成 2 年 5 月 20 日受理) 